ORIGINAL ARTICLE

\title{
Motor vehicle crash deaths related to police pursuits in the United States
}

\section{F P Rivara, C D Mack}

\author{
See end of article for \\ authors' affiliations \\ .................. \\ Correspondence to: \\ Dr Fred Rivara, \\ Harborview Injury \\ Prevention and Research \\ Center, Box 359960, 325 \\ Ninth Ave, Seattle, WA \\ 98104, USA; fpr@u. \\ washington.edu
}

Injury Prevention 2004;10:93-95. doi: 10.1136/ip.2003.004853

Objective: To determine the number and characteristics of motor vehicle crash deaths related to police pursuits in the United States.

Methods: Analysis of the Fatality Analysis Reporting System and the Crashworthiness Data System of the National Highway Traffic Safety Administration for the years 1994-2002.

Results: There were 2654 fatal crashes involving 3965 vehicles and 3146 fatalities during the nine year study period. Of these, 1088 were to people not in the fleeing vehicle. These crashes often occurred at high speed, in the night, on local roads. Most of the pursued drivers had prior motor vehicle related convictions. Conclusions: Many deaths related to police pursuits are to innocent victims. Given that most of the pursued drivers had prior convictions, alternative means of detaining them should be explored.
$\mathrm{H}$ igh speed pursuit of suspected criminals by police is controversial, ${ }^{1}$ and represents a balance between the need for apprehension of criminals and the potential risk to the pursuing police officer and the general public. The number of deaths each year far exceeds that due to any other police activity. ${ }^{2}$ A 1997 national survey of 436 police agencies indicated that $48 \%$ had revised their pursuit policies within the previous two years, with $87 \%$ placing more restrictions on police pursuits. ${ }^{3}$ The number of pursuits annually ranged from none to 870 , indicating substantial variation on how frequently police engage in pursuits. Case studies of more than 1200 pursuits in Miami, Florida, Omaha, Nebraska and Aiken, South Carolina found that pursuit related property damage occurred in $20 \%-40 \%$ of pursuits, and crashes resulting in injury in $12 \%-41 \%$ of all pursuits. ${ }^{3}$ Because of this high prevalence of motor vehicle crashes and injuries occurring during police pursuits, we sought to determine the number of fatal injuries annually in the United States related to pursuits, and the direct involvement of the individual in the pursuit to whom the fatal injury occurred.

\section{METHODS}

We used the publicly available Fatality Analysis Reporting System (FARS) operated by the National Highway Traffic Safety Administration to identify motor vehicle crashes related to police pursuit in which someone died. FARS is a complete sample of all motor vehicle crashes in the United States in which someone died within 30 days of the crash. FARS has a specific field in which the investigating officer must respond to whether the crash was police pursuit related or not. Data with this variable were available for 1994 through 2002.

In order to better evaluate the characteristics of police pursuit related fatal crashes, we compared them to crashes from the same years in the Crashworthiness Data System (CDS) operated by the National Highway Traffic Safety Administration. CDS has detailed data on approximately 5000 crashes selected by a stratified random sample of all police reported crashes in the United States involving property damage where a vehicle was towed from the crash or where there was an injury. These data were collected by trained field investigators using interviews, vehicle inspections, police reports, and medical records. The CDS values were weighted to account for the sampling scheme.

\section{RESULTS}

There were 260-325 police pursuits ending in a fatality annually in the United States for a total of 2654 crashes involving 3965 vehicles and 3146 fatalities during the nine year study period. Of the 3146 fatalities, 1088 deaths were of people not in the fleeing vehicle and 2055 to people in the fleeing vehicle (table 1). Altogether 102 (3.2\%) of the fatalities were non-motorists, 40 were police officers, 946 $(30.1 \%)$ were occupants of vehicles uninvolved in the police pursuit, and three were unknown. Most of the innocent deaths were motor vehicle occupants, with 102 being either pedestrians or bicyclists.

Comparing the fleeing vehicle drivers to all drivers in other fatal crashes identified in FARS and to all CDS reported crashes, fleeing drivers were more likely to be male, were younger, less likely to be restrained, and much more likely to be intoxicated or test positive for drugs (table 2). Only 39\% of the pursued drivers had a valid driver's license compared with $86 \%$ of drivers involved in other fatal crashes. Compared with drivers involved in other fatal crashes, the pursued drivers were more than twice as likely to have had previous convictions for driving while under the influence, three times as likely to have had their license previously suspended, and while they were equally likely to have had previous convictions for speeding, they were $60 \%$ more likely to have had other motor vehicle convictions.

The characteristics of the vehicles and crashes also differed between the two groups (tables 3 and 4). The vehicle was reported as stolen in $18 \%$ of cases compared with $0.2 \%$ of FARS vehicles not involved in police pursuits. The fleeing vehicles at the time of the crash were traveling a mean of $25.4 \mathrm{mph}(42.3 \mathrm{kph})$ over the speed limit compared to the CDS vehicles which were traveling a mean of $15.5 \mathrm{mph}$ $(25.8 \mathrm{kph})$ under the speed limit at the time of the crash. Almost one quarter of the pursuit crashes involved a rollover. Seven percent of the vehicles involved in pursuit crashes were motorcycles (compared with only $0.2 \%$ of CDS vehicles). Pursuit crashes were more likely to occur on local roads and during the night, but less likely to occur during inclement weather compared with other crashes.

Abbreviations: CDS, Crashworthiness Data System; FARS, Fatality Analysis Reporting System 
Table 1 Motor vehicle crash deaths related to police pursuits and all other crash deaths in the United States, 1994-2002

\begin{tabular}{llll}
\hline & $\begin{array}{l}\text { Fleeing vehicle } \\
\text { deaths* } \\
(\mathbf{n = 2 0 5 5 ) ; ~ \% ~}\end{array}$ & $\begin{array}{l}\text { Other pursuit } \\
\text { related deaths* } \\
(\mathbf{n}=1088) ; \%\end{array}$ & $\begin{array}{l}\text { Non-pursuit deaths, } \\
\text { FARS (n= 373276); } \\
\%\end{array}$ \\
\hline Male & 86.1 & 68.6 & 67.3 \\
Female & 13.9 & 31.4 & 32.7 \\
Mean age & 27.2 & 34.3 & 39.9 \\
(years) & & & \\
Driver & 61.0 & 52.7 & 54.2 \\
Passenger & 28.0 & 34.3 & 25.6 \\
Motorcyclist & 10.3 & 4.0 & 5.5 \\
Pedestrian & 0 & 8.5 & 12.6 \\
Bicyclist & 0 & 0.4 & 1.8 \\
Other/ & 0.7 & 0.1 & 0.3 \\
unknown & & & \\
\hline
\end{tabular}

*It could not be determined whether three of the deaths were occupants of the fleeing vehicle, so the total of deaths in this table is 3143 .

\section{DISCUSSION}

This study demonstrates that approximately 300 lives are lost each year in the United States from police pursuit related crashes and one third of these are among innocent people, not being pursued by police. These crashes occur in the dark at high speed often on local roads. The pursued usually have a long history of prior driving violations and are often intoxicated or using drugs. These 300 lives account for about $1 \%$ of all motor vehicle related deaths in the United States.

We could not determine the reason for the pursuit from these data. However, Alpert in his case study of three police departments found that $36 \%-51 \%$ of the pursuits were because of a traffic violation, compared with 35\%-43\% because of a felony. ${ }^{3}$ Auto theft is a common crime and

Table 2 Characteristics of fleeing vehicle drivers in police pursuit crash deaths compared with all drivers in fatal crashes and all drivers in police reported crashes in the United States, 1994-2002

\begin{tabular}{|c|c|c|c|}
\hline & $\begin{array}{l}\text { Fleeing vehicle } \\
\text { drivers in FARS } \\
(\mathbf{n = 2 2 4 4 ) ; \%}\end{array}$ & $\begin{array}{l}\text { Other drivers in } \\
\text { FARS fatalities } \\
(\mathrm{n}=507214) ; \%\end{array}$ & $\begin{array}{l}\text { Drivers in CDS } \\
\text { reported crashes } \\
\text { ( } n=57032 \text { ); } \\
\text { weighted \% }\end{array}$ \\
\hline Male & 92.7 & 72.6 & 55.8 \\
\hline Female & 6.8 & 26.0 & 43.1 \\
\hline Unknown & 0.5 & 1.4 & 0.1 \\
\hline $\begin{array}{l}\text { Mean age } \\
\text { (years) }\end{array}$ & 28.0 & 40.3 & 35.0 \\
\hline $\begin{array}{l}\text { Valid driver's } \\
\text { license }\end{array}$ & 38.7 & 86.4 & NA \\
\hline $\begin{array}{l}\text { Previous DWI } \\
\text { conviction }\end{array}$ & 10.5 & 3.3 & NA \\
\hline $\begin{array}{l}\text { Previous license } \\
\text { suspension }\end{array}$ & 35.5 & 11.7 & NA \\
\hline $\begin{array}{l}\text { Previous } \\
\text { speeding } \\
\text { conviction }\end{array}$ & 20.2 & 20.8 & NA \\
\hline $\begin{array}{l}\text { Previous other } \\
\text { driving violation } \\
\text { conviction }\end{array}$ & 25.9 & 16.5 & NA \\
\hline Unrestrained & 67.6 & 35.7 & 14.1 \\
\hline Restrained & 18.1 & 54.1 & 64.1 \\
\hline $\begin{array}{l}\text { Restraint use } \\
\text { unknown }\end{array}$ & 14.3 & 10.2 & 21.2 \\
\hline $\begin{array}{l}\text { BAC tested and } \\
\geqslant 0.1 \mathrm{~g} / \mathrm{dl}\end{array}$ & 30.6 & 12.9 & 3.2 \\
\hline $\begin{array}{l}\text { Drug screen } \\
\text { positive }\end{array}$ & 16.6 & 4.4 & 0.8 \\
\hline $\begin{array}{l}\text { Drug screen } \\
\text { negative }\end{array}$ & 0 & 0 & 1.3 \\
\hline
\end{tabular}

Table 3 Characteristics of vehicles in fatal crashes related to police pursuit compared to all other fatal crashes and to all police reported crashes in the United States, 1994-2002

\begin{tabular}{|c|c|c|c|}
\hline & $\begin{array}{l}\text { Vehicles in fatal } \\
\text { police pursuit } \\
\text { crashes } \\
(\mathrm{n}=3965) ; \%\end{array}$ & $\begin{array}{l}\text { Vehicles in } \\
\text { other fatal } \\
\text { crashes } \\
(n=506629) \text {; } \\
\%\end{array}$ & $\begin{array}{l}\text { All CDS } \\
\text { vehicles } \\
(n=69016) ; \\
\text { weighted \% }\end{array}$ \\
\hline Stolen vehicle & $11.2^{*}$ & 0.2 & NA \\
\hline $\begin{array}{l}\text { Mean speed limit in } \\
\mathrm{mph}(\mathrm{kph})\end{array}$ & $43.8(73.0)$ & $50.4(84.0)$ & $40.4(67.3)$ \\
\hline $\begin{array}{l}\text { Number of mph (kph) } \\
\text { over or under the } \\
\text { speed limit }\end{array}$ & $25.4(42.3)$ & $6.1(10.2)$ & $\begin{array}{l}-15.5 \\
(-25.8) \dagger\end{array}$ \\
\hline Rollover & 21.6 & 18.1 & 5.2 \\
\hline Passenger car & 65.4 & 50.8 & 66.4 \\
\hline Utility vehicle & 6.8 & 8.2 & 9.6 \\
\hline Pickup & 12.7 & 18.9 & 14.1 \\
\hline Van & 4.7 & 6.4 & 6.8 \\
\hline Motorcycle & 7.0 & 4.5 & 0.2 \\
\hline Other or unknown & 0.6 & 1.9 & 0.1 \\
\hline
\end{tabular}

${ }^{*} 17.6 \%$ of fleeing vehicles were reported as stolen, $3.1 \%$ of unpursued, non-police vehicles, $0.7 \%$ of police cars.

†Missing for $70 \%$ of CDS crashes. Not all vehicles were in motion.

$18 \%$ of the pursued vehicles in our study had been stolen. In one trauma center study, $8 \%$ of all motor vehicle crash related injuries during 1993-94 involved a stolen car. ${ }^{4}$ In that study, $42 \%$ of the victims were innocent and the case-fatality rate was $18 \%$ compared with $7 \%$ for all motor vehicle injured patients treated at that center.

We also could not determine from our data the proportion of police pursuits that ended in a crash or a fatality. However, in Alpert's study of three jurisdictions, $20 \%-40 \%$ ended in a crash and $12 \%-41 \%$ of pursuits result in an injury. ${ }^{3}$ In data from California and Miami during the 1980s, $1 \%$ and $0.7 \%$ of police pursuits respectively resulted in fatalities ${ }^{2}$. In Illinois, $1.7 \%$ resulted in deaths. ${ }^{2}$ While nearly all police agencies have written policies governing pursuits, $48 \%$ permitted pursuits in response to any offense, not just a felony offense. ${ }^{5}$ Only $11 \%$ placed limits on pursuing speeds.

The study also suggests a number of areas in which further research might be helpful for determining public policy. The wide range in the number of police pursuits in different police jurisdictions across the country represents a natural experiment in which the effects of different policies on crime might be investigated. Is the trade-off of fewer pursuit related crashes and deaths offset by a higher number of fatal crimes, crashes involving alcohol, and a lack of apprehension of serious criminal offenders? The data may be available for a true cost-benefit analysis in which different policies for pursuit could be modeled. Are criminals aware of a jurisdiction's pursuit policy, and does it affect their likelihood

Table 4 Characteristics of fatal crashes related to police pursuit compared to all other fatal crashes and to all police reported crashes in the United States, 1994-2002

\begin{tabular}{|c|c|c|c|}
\hline & $\begin{array}{l}\text { Fatal police } \\
\text { pursuit crashes } \\
(n=2654) ; \%\end{array}$ & $\begin{array}{l}\text { Other fatal } \\
\text { crashes } \\
(n=333153) ; \%\end{array}$ & $\begin{array}{l}\text { All CDS crashes } \\
\text { (n=39223); } \\
\text { weighted } \%\end{array}$ \\
\hline Local road & 38.1 & 23.4 & NA \\
\hline Arterial & 43.1 & 56.4 & NA \\
\hline Country road & 17.8 & 19.2 & NA \\
\hline $\begin{array}{l}\text { Hazardous } \\
\text { weather }\end{array}$ & 5.6 & 12.1 & 20.3 \\
\hline Night-time & 71.9 & 47.1 & 33.5 \\
\hline
\end{tabular}




\section{Key points}

- High speed pursuit of suspected criminals by police is controversial, and represents a balance between the need for apprehension of criminals and the potential risk to the pursuing police officer and the general public.

- There were 260-325 police pursuits ending in a fatality annually in the United States during the nine year study period 1994-2002.

- A total of 1088 deaths were of people not in the fleeing vehicle and 2055 to people in the fleeing vehicle.

- Altogether 946 (30.1\%) were occupants of vehicles uninvolved in the police pursuit.

- Only $39 \%$ of the pursued drivers had a valid driver's license compared with $86 \%$ of drivers involved in other fatal crashes.

of fleeing the scene of a crash or police arrest? What other alternatives to police pursuits are available and what is their relative effectiveness?

Police pursuit policies must be informed by this type of research, and public debate about these policies be conducted. Police pursuits are hotly debated among the law enforcement and criminal justice community. ${ }^{2}$ Policies vary in the type of offense for which a pursuit is allowed, the speed at which they can be conducted, responsibility for initiating and terminating a pursuit, and the use of alternatives. $^{5}$ Changes in policies can have a substantial effect. For example, when Dade County, Florida restricted pursuits to only those for violent felons, the number of police pursuits decreased by $82 \%$ in the next year. ${ }^{3}$ In contrast, when Omaha adopted a more permissive policy for pursuit, the number of pursuits increased by $600 \%{ }^{3}$ Prior research indicates a relative lack of training of officers in pursuits and pursuit driving. ${ }^{3}$ Other methods of stopping criminals have not been widely adopted such as use of roadblocks, barrier strips which have spikes designed to puncture the tires and stop the pursued vehicle. ${ }^{5}$ Pursuit incidents are often not routinely reviewed by the agency, and $40 \%$ of agencies reported providing no training in pursuit tactics. ${ }^{5}$ Given that one third of the deaths are to innocent civilians, the cost and benefits of police pursuits should be more openly discussed and other options for stopping criminals more fully explored.

\section{ACKNOWLEDGEMENT}

Grant R49/CCR0002570 from the Centers for Disease Control and Prevention.

\section{Authors' affiliations \\ F P Rivara, Harborview Injury Prevention and Research Center and Departments of Pediatrics and Epidemiology, University of Washington, Seattle \\ C D Mack, Departments of Pediatrics and Epidemiology, University of Washington, Seattle}

\section{REFERENCES}

1 Copeland AR. Deaths resulting from police pursuit. Am J Forensic Med Pathol 1988:9:228-32.

2 Alpert GP, Clarke AC, Smith WC. The constitutional implications of highspeed police pursuits under a substantive due process analysis: homeward through the haze. University of Memphis Law Review 1997:27.

3 Alpert GP. Police pursuit: policies and training. Washington, DC: National Institute of Justice, 1997: 1-8.

4 Livingston DH, Merritt S, Callori S, et al. Auto theft-related trauma. J Trauma 1998;45:780-3; discussion 783-4.

5 Kenney DJ, Alpert GP. A national survey of pursuits and the use of police force: data from law enforcement agencies. Journal of Criminal Justice 1997;25:315-23.

\section{LACUNAE}

\section{Reducing assaults}

new approach to reducing alcohol related assaults and other antisocial behaviours in - inner city entertainment precincts has been announced in Melbourne, Australia. During the one year trial period, hospitals will be encouraged to transfer information directly to police when people present to hospitals with injuries sustained at entertainment venues. The project will establish a database of incidents to enable police to track trends and to follow up with licensees to provide additional information from security camera film and other records. Police will "work with licensees to ensure that appropriate guidelines, training and staff were put in place" (contributed by Jan Shield, from The Age (Melbourne), January 2004).

\section{Trolley crash tests}

An Australian insurance group, the NRMA, has conducted what it believes to be the world's first shopping trolley crash test on behalf of the insurance industry. The report was commissioned after it was found that abandoned or runaway trolleys cause about Aus $\$ 1$ million (US\$ 750 000) damage to cars each year (contributed by Ian Scott, from The Age (Melbourne), November 2003. Ian comments that the report makes no mention of the long standing issue of child falls from trolleys). 